УДК $378 ; 371: 14$

DOI:

Ольга Колодницька, кандидат педагогічних наук, викладач кафедри іноземних мов Тернопільського національного медичного університету імені І.Я. Горбачевського

\title{
ВИКОРИСТАННЯ ПЕДАГОГІЧНОГО ТРЕНІНГУ В ПРОЦЕСІ СТИМУЛЮВАННЯ ПРОФЕСІЙНОГО САМОРОЗВИТКУ МАЙБУТНЬОГО ВЧИТЕЛЯ-ГУМАНІТАРІЯ
}

Проаналізовано поняття “тренінг”, “педагогічний тренінг”, особливості використання педагогічного тренінгу, основні принципи його проведення. Обгрунтовано діяльність викладача-тренера під час проведення тренінгу, основні вимоги до викладача-тренера в прочесі стимулювання професійного саморозвитку майбутніх вчителів-гуманітаріїв.

Наведено приклад педагогічного тренінгу на тему: "Саморозвиток особистості як психологопедагогічна проблема”, який побудований за принципом гри з використанням потенційних резервів учительської підсвідомості.

Ключові слова: педагогічний тренінг; вчитель-гуманітарій; викладач-тренер; стимулювання; професійний саморозвиток.

Табл. 1. Лім. 6.

Olha Kolodnytska, Ph.D.(Pedagogy), Lecturer of the Foreign Language Department Ternopil Ivan Horbachevskiy National Medical University

\section{USE OF PEDAGOGICAL TRAINING IN PROCESS OF PROFESSIONAL SELF- DEVELOPMENT OF FUTURE TEACHER OF HUMANITIES}

The article analyses the terms "training", "pedagogical training", the peculiarities of the use of pedagogical training, the basic principles of the training. The activity of a teacher-trainer during the training, the main requirements for the teacher-trainer in the process of stimulation of professional self-development of future teachers of Humanities is substantiated. It was revealed that the use of pedagogical training with all the necessary elements of group dynamics of professional self-development of future teachers of Humanities significantly facilitates their creative professional training.

The author represents the sample of the pedagogical training "Self-development of the person as a psychological and pedagogical problem". It was constructed on the principle of the game using the potential reserves of the teacher's subconscious. The purpose of this pedagogical training was to build confidence in the right choice of profession by transforming the acquired knowledge into skills and abilities, to create a working atmosphere in a group, the ability to work and communicate in a team, to improve professional level by solving various tasks.

The pedagogical training is divided into the organizational stage: greetings of all participants, an announcement of the topic of the training, the main body: a complex of reflexive and diagnostic exercises, aimed at developing the internal motivation, creativity, critical thinking, memory, imagination, prognostic abilities that are needed in planning professional self-development and future pedagogical activity, revealing the degree of personal and professional growth, the totality of acquired professional qualities and abilities, assessment of their level of expressiveness, the final part: a summarizing, reflective activities, an individual self-report, a group analysis, an expert evaluation.

Keywords: a pedagogical training; a future teacher of Humanities; a teacher trainer; stimulation; a professional self-development.

П остановка проблеми у загальному її вигляді. Суттєвою перевагою тренінгових технологій є те, що вони дають унікальну можливість вивчити складні, емоціино значимі питання в безпечніи обстановці тренінгу, а не в реальному житті з його загрозами та ризиками $[5,7]$.

Педагогічний тренінг, на нашу думку, забезпечує здійснення професійної підготовки майбутнього вчителя-гуманітарія, спрямованої на розвиток його професійних й особистісних якостей, сприяє його саморозвитку й самореалізації шляхом трансформації здобутих знань у вміння, навички, якості, які необхідні на світовому ринку праці.

Проблема застосування тренінгу в процесі стимулювання професійного саморозвитку майбутнього вчителя-гуманітарія залишається недостатньо дослідженою i потребує теоретичного обгрунтування.

Аналіз останніх досліджень і публікацій. Основні аспекти теоретичних і методичних основ тренінгового навчання розглянено в дослідженнях українських (С. Архіпова, Л. Журавська, Н. Рудюк, А. Семенова, В. Федорчука, Т. Яценко та ін.) та зарубіжних науковців (Ю. Смельянов, 
С. Конг, А. Маслоу, Л. Петровська, К. Роджерс та ін.).

Формулювання цілей статті. Мета статті - проаналізувати особливості використання педагогічного тренінгу та основні вимоги до викладача-тренера в процесі стимулювання професійного саморозвитку майбутніх вчителівгуманітаріїв; розробити педагогічний тренінг.

Виклад основного матеріалу. Тренінг особливий метод отримання знань, який дає змогу всім його учасникам навчатися на власному досвіді у момент його проведення. Він створює сприятливе середовище, у якому кожен може легко та із задоволенням усвідомити свої плюси i мінуси, досягнення і поразки. Швидке розуміння власних особистісних якостей і розвиток відповідних професійних умінь і навичок набувається завдяки допомозі й увазі навколишніх. Ситуація тренінгу є навчальною, жоден із його учасників не ризикує уже сформованими відносинами та поглядами, а набуває й використовує новий досвід. Будь-яка навичка або якість моделюються конкретними кроками та негайно аналізуються i перевіряються в умовах навчальної діяльності, максимально наближеної до реальності на тренінговому занятті. Таким чином, тренінг навчає гнучкості, спілкування, прийняттю позиції іншого, що є корисним у житті й професійнотворчій діяльності $[2,70]$.

Педагогічний тренінг - це форма організації діяльності у процесі індивідуалізації професійнопедагогічної підготовки, спрямованої на розвиток особистісних і професійних якостей особистості майбутнього учителя, шляхом актуалізації знань у стійкі психічні угворення: уміння, навички, якості, які реалізуються у процесі відновлювального тренування окремих дій в умовах індивідуалізації, систематичності, повторення, зростаючого навантаження та рефлексивної оцінки результату $[6,11]$.

Ефективність педагогічного тренінгузалежить від засобів і вмінь викладача впливати на учасників групи. У психолого-педагогічній літературі обгрунтовано діяльність викладачатренера, яка розкривається у відповідних функціях: керівній, організаторській, консультативній, інформаційній й аналітичній. Викладач-тренер, виконуючи зазначені функції, створює особливу атмосферу в групі, сприяє саморозкриттю і самореалізації всіх іiї учасників [3, 39].

Основні вимоги до викладача-тренера [1]:

1) управлінські ролі та функції, організаційні уміння, уміння формувати команди, навички консультування, чуйність, здатність швидко відновлювати фізичні і душевні сили, здатність до самопізнання і саморозвитку, креативність, упевненість у собі;

2) володіння методикою розробки навчальнометодичних матеріалів і проведення тренінгу, вміння вести робочу документацію, працювати 3 матеріально-технічними ресурсами.

Викладач-тренер розробляє концепцію тренінгу, забезпечуючи всі потреби його учасників. Зазначена концепція тренінгу інтегрує систему поглядів, підходів до вирішення цілей та їх завдань, і $€$ інструментом управління змістом тренінгу, містить детальну робочу програму, інструкції, інформаційні повідомлення, методичне забезпечення, визначену тематику й кількість годин на висвітлення тієї чи іншої теми заняття. Викладач-тренер повинен підготовити тренінг максимально передбачаючи всі складні запитання або висловлювання, які виникатимуть у групі під час його проведення. Важливим завданням його $\epsilon$ вибір таких методів, прийомів і засобів для проведення тренінгу, які залежать від цілей та його змісту [4].

У контексті нашого дослідження ефективними методами вважаємо методи проблемного навчання й активні методи групового навчання (дискусію, монологічний метод навчання, діалогічний метод навчання, евристичний метод навчання, дослідницький метод навчання, метод ігрового моделювання, метод проектів, метод незакінчених речень тощо).

Проведення тренінгу відбувається за чіткою структурою. Структура, мета та завдання тренінгу $є$ основою для складання плану проведення. Як приклад, наведемо зміст і хід тренінгу “Саморозвиток особистості як психолого-педагогічна проблема”.

Таблиця 1.

Тренінг: “Саморозвиток особистості як психолого-педагогічна проблема”

Мета - сформувати впевненість у правильному виборі професії, створити робочу атмосферу в групі, вчитися діяти та спілкуватися в колективі, підвищувати професійний рівень шляхом вирішення різноманітних завдань.

Методи: монологічний метод навчання, діалогічний метод навчання, евристичний метод навчання, дослідницький метод навчання, метод ігрового моделювання, дискусія, метод проектів, метод незакінчених речень.

Форми роботи: колективна та індивідуальна самостійна робота, індивідуальна, парна, групова робота. 
Продовження таблиці 1.

Засоби: словесні, наочно-ілюстративні, інформаційно-комунікативні, технічні засоби навчання.

Педагогічні умови: забезпечення постійного позитивного мотивування; набуття досвіду інноваційної педагогічної діяльності.

\begin{tabular}{|c|c|c|c|}
\hline Emanu & $\begin{array}{l}\text { Форми } \\
\text { роботи }\end{array}$ & $\begin{array}{l}\text { Ресурсне } \\
\text { забезпечення }\end{array}$ & $\begin{array}{l}\text { Тривалість } \\
\text { тренінгу }\end{array}$ \\
\hline \multicolumn{4}{|l|}{ Організаиійна частина: } \\
\hline $\begin{array}{l}\text { Вітання. На початку тренінгу учасники вітають один } \\
\text { одного рукостисканням. Кожен із учасників підходить } \\
\text { по черзі до усіх інших учасників потискує руку } \\
\text { партнера і говорить йому щось приємне (комплімент, } \\
\text { побажання ). }\end{array}$ & $\begin{array}{l}\text { індивіду } \\
\text { альна } \\
\text { робота }\end{array}$ & & $5 \mathrm{XB}$ \\
\hline $\begin{array}{l}\text { Знайомство учасників } \\
\text { Вправа } 1 .\end{array}$ & $\begin{array}{l}\text { групова } \\
\text { робота }\end{array}$ & $\begin{array}{l}\text { слайди } 3 \\
\text { запитаннями }\end{array}$ & $10 \mathrm{XB}$ \\
\hline Знайомство учасників, самопрезентація. & & & \\
\hline \multicolumn{4}{|l|}{$\begin{array}{l}\text { “Якими якостями повинен володіти педагог- } \\
\text { професіонал?”. } \\
\text { Версія відповіді: цілеспрямованість, наполегливість, } \\
\text { працьовитість ... Сукупність усіх цих якостей визначає } \\
\text { ідеального вчителя. } \\
\text { Респонденти діляться на мікрогрупи чисельністю по } \\
\text { чотири. }\end{array}$} \\
\hline \multicolumn{4}{|l|}{ Вирава 2.} \\
\hline $\begin{array}{l}\text { Знайомство учасників, самопрезентація. } \\
\text { Респонденти діляться на мікрогрупи } \\
\text { чисельністю по чотири. }\end{array}$ & $\begin{array}{l}\text { групова } \\
\text { робота }\end{array}$ & $\begin{array}{l}\text { слайди } \\
\text { запитаннями, } \\
\text { картки, } \\
\text { маркери, } \\
\text { папір, ручки }\end{array}$ & $15 \mathrm{xB}$ \\
\hline \multicolumn{4}{|l|}{$\begin{array}{l}\text { “Як зміниться ідеальний вчитель, якщо у нього буде } \\
\text { відсутня одна } 3 \text { цих якостей?”. }\end{array}$} \\
\hline $\begin{array}{l}\text { Рефлексія: Чи легко характеризувати себе й інших } \\
\text { учасників тренінгу? }\end{array}$ & & & $5 \mathrm{xB}$ \\
\hline Разом: & & & $35 \mathrm{xB}$ \\
\hline \multicolumn{4}{|l|}{ Основна частина: } \\
\hline \multicolumn{4}{|l|}{ Вирава 3.} \\
\hline $\begin{array}{l}\text { Розвиток } \quad \text { нестандартності } \\
\text { гнучкості, } \\
\text { здритлення, } \\
\text { кдатнсті генерувати нові ідеї. } \\
\text { Респонденти діляться на дві групи. }\end{array}$ & $\begin{array}{l}\text { колектив } \\
\text { на } \\
\text { самостій } \\
\text { на } \\
\text { робота, } \\
\text { групова } \\
\text { робота }\end{array}$ & $\begin{array}{l}\text { сценарій } \\
\text { байки }\end{array}$ & $20 \mathrm{XB}$ \\
\hline \multicolumn{4}{|l|}{$\begin{array}{l}\text { Написати байку, мораллю якої служать: } \\
\text { а) відомий афоризм (наприклад, мова - засіб зближення } \\
\text { далеких народів і роз’єднання сусідів по квартирі; душі, } \\
\text { звичайно, немає, але іноді вона все-таки поболює); } \\
\text { б) життєве правило або неписаний закон. } \\
\text { Програти цю байку. }\end{array}$} \\
\hline $\begin{array}{l}\text { Рефлексія: Чи всі погоджуються } 3 \text { з такими } \\
\text { висловлюваннями? Відповідь обгрунтуйте. }\end{array}$ & & & $5 \mathrm{xB}$ \\
\hline \multicolumn{4}{|l|}{ Вирава 4.} \\
\hline \begin{tabular}{lccr}
\multicolumn{2}{l}{ налаштування } & на роботу & в групі, \\
розвиток & вербальних & здібностей, \\
підвищення & культури & мови \\
спілкування & & &
\end{tabular} & $\begin{array}{l}\text { робота в } \\
\text { парах }\end{array}$ & $\begin{array}{l}\text { картки, слайди } \\
\text { iз описом } \\
\text { ідеального та } \\
\text { неуспішного }\end{array}$ & $25 \mathrm{XB}$ \\
\hline
\end{tabular}


Продовження таблиці 1.

\begin{tabular}{|c|c|c|c|}
\hline $\begin{array}{l}\text { “Театр пантоміми”. Необхідно за допомогою жестів і } \\
\text { міміки зобразити: } \\
\text { а) ідеального вчителя; } \\
\text { б) неуспішного вчителя. }\end{array}$ & & & \\
\hline Рефлексія: Які ролі виконує вчитель на занятті? & & & $5 \times \mathrm{xB}$ \\
\hline \multicolumn{4}{|c|}{ Перерва 30 хв } \\
\hline Вирава 5. & & & \\
\hline $\begin{array}{l}\text { розвиток творчого ставлення } \\
\text { майбутніх учителів до своєї професії, } \\
\text { до самих себе }\end{array}$ & $\begin{array}{l}\text { індивідуальна } \\
\text { самостійна } \\
\text { робота }\end{array}$ & $\begin{array}{l}\text { використання } \\
\text { попередньо } \\
\text { складених карт- } \\
\text { схем, коротких } \\
\text { тез, презентацій }\end{array}$ & $45 \mathrm{xB}$ \\
\hline $\begin{array}{l}\text { А) Учасники тренінгу презентують себе в якості } \\
\text { вчителя. } \\
\text { Б) Складіть план професійного зростання на п’ять } \\
\text { років. Намагайтесь охопити всі сторони свого життя: } \\
\text { здоров’я, характер, кар'єру, гроші, середовище } \\
\text { спілкування, відпочинок, сім'ю. Визначте пріоритети, } \\
\text { основні завдання, проблеми й способи їх вирішення. } \\
\text { Подумайте, яким стане життя, якщо план буде } \\
\text { виконаним? Що вже зараз можна для цього зробити? } \\
\text { Кожний учасник зачитує свій план професійного } \\
\text { зростання на п’ять років. }\end{array}$ & & & \\
\hline $\begin{array}{l}\text { Рефлексія: Чи, на вашу думку, це реально? } \\
\text { Дайте цінні поради. }\end{array}$ & & & $10 \mathrm{xB}$ \\
\hline $\begin{array}{l}\text { Викладач-тренер уважно спостерігає за } \\
\text { тим, щоб формулювання мали } \\
\text { виключно позитивне спрямування. } \\
\text { Наприклад, формулювання: “Мені буде } \\
\text { приємно бути присутнім на занятті, } \\
\text { якщо учасники не наполягатимуть на } \\
\text { виконанні мною усіх вправ” викладач- } \\
\text { тренер пропонує замінити на таке: } \\
\text { “Мені буде приємно брати участь у } \\
\text { вправі, чи ні?” }\end{array}$ & & & $5 \times \mathrm{xB}$ \\
\hline Разом: & & & $\begin{array}{l}1 \quad \text { год } \\
40 \mathrm{xв}\end{array}$ \\
\hline \multicolumn{4}{|l|}{ Підсумкова частина: } \\
\hline Вправа 6. “Вільний мікрофон” & $\begin{array}{l}\text { групова } \\
\text { робота }\end{array}$ & мікрофон & $10 \mathrm{xB}$ \\
\hline \begin{tabular}{l|l} 
Mema & $\begin{array}{l}\text { Обмін враженнями студентів- } \\
\text { гуманітаріїв від змістового наповнення } \\
\text { та форми проведення тренінгу. }\end{array}$ \\
\end{tabular} & & & \\
\hline $\begin{array}{l}\text { Визначення } \begin{array}{c}\text { кожним } \\
\text { отриманої }\end{array} \text { інформації } \quad \text { у } \quad \text { контексті } \\
\text { методичної проблеми. } \\
\text { Підсумовуючи роботу під час тренінгу, завершіть } \\
\text { думку: } \\
\text { Сьогодні мене вразило... } \\
\text { Мені запам’яталося ... } \\
\text { Мене дратувало ... } \\
\text { Мені було цікаво/не цікаво ... }\end{array}$ & & & \\
\hline $\begin{array}{l}\text { Рефлексія: - Які відкриття для себе Ви зробили під } \\
\text { час сьогоднішньої зустрічі? } \\
\text { - Яку Ви бачите перспективу застосування отриманої } \\
\text { інформації в своїй діяльності? }\end{array}$ & & & $10 \mathrm{xB}$ \\
\hline
\end{tabular}




\begin{tabular}{|c|c|c|c|c|}
\hline & & & \multicolumn{2}{|c|}{ Продовження таблиці 1.} \\
\hline \multicolumn{2}{|c|}{ Вправа 7. "Дружнє рукостискання" } & $\begin{array}{l}\text { індивідуальна } \\
\text { робота }\end{array}$ & $\begin{array}{l}\text { маркери, } \\
\text { ватман }\end{array}$ & $5 \mathrm{xB}$ \\
\hline Mema & створення позитивного настрою & & & \\
\hline \multicolumn{5}{|c|}{$\begin{array}{l}\text { Респонденти на ватмані паперу пишуть своє } \\
\text { прізвище і побажання. }\end{array}$} \\
\hline \multicolumn{2}{|c|}{ Разом } & & & $25 \mathrm{xB}$ \\
\hline \multicolumn{2}{|c|}{ Підсумки тренінгу } & & & $5 \mathrm{xB}$ \\
\hline \multicolumn{2}{|c|}{ Тривалість тренінгу } & & & 3 год 30 хв \\
\hline
\end{tabular}

Вищенаведений тренінг тривалістю три години 30 хвилин розрахований на групу до 30 осіб. Для кращого розуміння змісту заняття пропонуємо розглянути иого окремі частини.

Усі етапи тренінгу (організаційний етап: привітання всіх членів групи, оголошення теми тренінгу, основна частина: комплекс рефлексивних і діагностуючих вправ, підсумкова частина: підведення підсумків, рефлексія діяльності, індивідуальний самозвіт, груповий аналіз заняття, експертна оцінка) взаємопов'язані й сприяють поступовому переходу до наступних.

Організаційна частина тренінгу грунтується на чітко визначених часових межах (короткотривалість), спрямуванні на подальшу роботу, простоті у застосуванні й прогностичності.

Респондентам було запропоновано різні запитання, наприклад: “Якими якостями повинен володіти педагог-професіонал?”. Версії відповіді: цілеспрямованість, наполегливість, ініціативність, працелюбність, ерудованість, уміння аналізувати, інтегрувати, синтезувати інформацію, повага до студентів/учнів, знання свого предмету, почуття гумору. Сукупність усіх цих якостей визначає ідеального вчителя. Відповідно до евристичного методу “Як ..." питання змінювалося: “Як зміниться ідеальний вчитель, якщо у нього буде відсутня одна 3 цих якостей?”. Майбутні вчителі гуманітарного профілю ділились на мікрогрупи чисельністю по чотири. Кожній мікрогрупі було дано по одній “відсутній” якості. Через 4-5 хвилин кожна мікрогрупа по черзі висловлювала свою думку, а інші намагалися іiі спростувати.

Основна частина тренінгу складалася 3 вправ на розвиток внутрішньої мотивації, удосконалення комунікативних і організаторських навичок, виявлення творчості, дискусійних запитань і їх обговорення, рольової гри (вправи 3 , 4).

Для усвідомлення майбутнім вчителем гуманітарного профілю своїх дій, результату і власного внеску у процес професійного саморозвитку було обговорено кожну вправу. Це сприяло кращому розумінню один одного, професійних інтересів і захоплень своїх одногрупників, поліпшувало мікроклімат у колективі, інтенсифікувало їхню рефлексивну діяльність. Викладачеві лише залишалося не дати згаснути інтересу, підтримати й розвинути відповідну мотивацію, що й сприяло реалізації першої педагогічної умови забезпеченню постійного позитивного мотивування.

Зокрема, кожному з учасників тренінгу було дано можливість презентувати себе в якості вчителя (вправа 5). Респонденту пропонувалося протягом 5 хвилин написати/презентувати стисле повідомлення, $з$ якого можна було б дізнатися про нього як про вчителя. Кожний зачитує/презентує повідомлення, учасники ставлять запитання для уточнення. Вправа спрямована на розвиток позитивного самосприйняття, мотивації, розвиток умінь самопрезентації.

Важливе значення для становлення студентів як майбутніх учителів гуманітарного профілю має їхня творча активність на заняттях і правильна організація власної діяльності (реалізація другої педагогічної умови - набуття досвіду інновачійної педагогічної діяльності).

Підсумкова частина тренінгу - це етап заняття, на якому підводяться підсумки (рефлексія) й здійснюється аналіз і самоаналіз, оцінка досягнених результатів власної діяльності іншими учасниками тренінгового заняття і викладачем-тренером (експертна оцінка), встановлюється зворотний, усвідомлений зв' язок між усіма учасниками тренінгового заняття, які діляться власними враженнями та думками.

На підсумковій частині тренінгу респондентам було запропоновано вправи “Вільний мікрофон” та “Дружнє рукостискання”. Виконання вправ передбачало обмін враженнями студентівгуманітаріїв від змістового наповнення та форми проведення тренінгу. Визначення кожним учасником актуальності отриманої інформації та 
перспектив для здійснення подальших розвідок у контексті особистої методичної проблеми.

Учасникам пропонується відповісти на такі запитання:

1. Що нового Ви дізналися під час сьогоднішньої зустрічі?

2. Яку Ви бачите перспективу застосування отриманої інформації в своїй професійній діяльності?

Висновки. Таким чином, тренінг сприяє вдосконаленню мотиваційної, комунікативної, творчої та рефлексивної сфери особистості майбутнього вчителя-гуманітарія, стимулює його професійний саморозвиток. Вважаємо, що педагогічний тренінг є формою організації процесу стимулювання професійного саморозвитку, який дає змогувиявити потенціал кожного майбутнього гуманітарія із урахуванням його індивідуальних особливостей, удосконалити професійні й особистісні якості, стимулює його професійний саморозвиток і самовдосконалення.

Безумовно, педагогічний тренінг як форму організації діяльності необхідно вдосконалювати, розвивати для підготовки конкурентоспроможних вчителів-гуманітаріїв відповідно до вимог сучасного ринку праці.

Перспективи подальших розвідок у даному напрямі. Перспективи подальших розвідок щодо використання педагогічного тренінгу в процесі стимулювання професійного саморозвитку майбутнього вчителя-гуманітарія ми вбачаємо у глибшому аналізі проблеми його використання і розробці необхідних тренінгових програм із професіино-орієнтованих дисциплін.

\section{ЛІТЕРАТУРА}

1. Бондарєва Л. І. Навчальний тренінг як засіб професійної підготовки майбутніх менеджерів організацій в економічних університетах : автореф. дис. на здобуття наук. ступеня канд. пед. наук : спец. 13.00.04 “Теорія та методика професійної освіти”. Київ, 2006. 23 с.

2. Гладышев С. Как вести себя на тренинге? Обучение и карьера. 2005. № 35. С. 70.
3. Зайцева Т. В. Теория психологического тренинга. Психологический тренинг как инструментальное действие. Санкт Петербург; Москва, 2002. 80 с.

4. Игра в тренинге. Возможности игрового взаимодействия / под ред. Е. А. Левановой. Санкт Петербург, 2006. 208 с.

5. Шоробура I. Тренінгові технологіi у закладах вищоі освіти. Молодь і ринок. 2019. № 2. С. 6 - 12 .

6. Щербань П. М. Навчально-педагогічні ігри у вищих навчальних закладах : навч. посібник. Київ, 2004. 207 с.

\section{REFERENCES}

1. Bondarieva, L. I. (2006). Navchalnyi treninh yak zasib profesiinoi pidhotovky maibutnikh menedzheriv orhanizatsii $\mathrm{v}$ ekonomichnykh universytetakh [Training as a tool of professional training of future managers of organizations in economic universities]. Extended abstract of candidate's thesis. [in Ukrainian].

2. Gladyshev, S. (2005). Kak vesti sebya na treninge? [How to behave at the training?]. Obuchenie i karera. Vol.35, p. 70. [in Russian].

3. Zajceva, T. V. (2002). Teoriya psihologicheskogo treninga. Psihologicheskij trening kak instrumentalnoe dejstvie [Theory of psychological training. Psychological training as an instrumental action]. St.Petersburg; Moscow, 80 p. [in Russian].

4. Levanova, E. A. (Ed.). (2006). Igra v treninge. Vozmozhnosti igrovogo vzaimodejstviya [Game training. The possibilities of game interactions]. St.Petersburg, 208 p. [in Russian].

5. Shorobura, I. (2019). Treninhovi tekhnolohii u zakladakh vyshchoii osvity [Training technologies in higher education institutions]. "Youth and market". Monthly scientific-pedagogical journal. Drogobych, Vol.2 (169), pp. 6-12. [in Ukrainian].

6. Shcherban, P. M. (2004). Navchalnopedahohichni ihry u vyshchykh navchalnykh zakladakh : navch. Posibnyk [Educational and pedagogical games in higher educational establishments: a manual]. Kyiv, 207 p. [in Ukrainian].

Стаття надійшла до редакції 23.05.2019

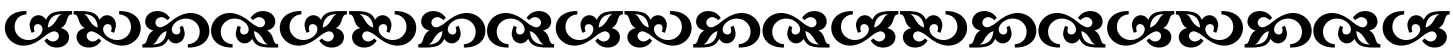

"Хто споглядав велич природи, той $i$ сам прагне до досконалості $і$ гармонії. Наш внутрішній світ повинен уподібнюватися иим зразком. У чистій атмосбері все чисто".

Oноре де Бальзак браниузький романіст і драматург

\section{G58080}

